\title{
Metallic Nanoparticle-Decorated Polydopamine Thin Films and Their Cell Proliferation Characteristics
}

\author{
Ferhunde Aysin ${ }^{1,2}$, Asli Yilmaz ${ }^{2,3}$ and Mehmet Yilmaz 2,4,5,*价 \\ 1 Department of Biology, Ataturk University, 25240 Erzurum, Turkey; ferhundeaysin@gmail.com \\ 2 East Anatolia High Technology Application and Research Center (DAYTAM), Ataturk University, \\ 25240 Erzurum, Turkey; asli.yilmaz@atauni.edu.tr \\ 3 Department of Molecular Biology and Genetics, Ataturk University, 25240 Erzurum, Turkey \\ 4 Department of Chemical Engineering, Ataturk University, 25240 Erzurum, Turkey \\ 5 Department of Nanoscience and Nanoengineering, Ataturk University, 25240 Erzurum, Turkey \\ * Correspondence: nano.yilmaz@gmail.com; Tel.: +90-535-388-70-63
}

Received: 22 July 2020; Accepted: 17 August 2020; Published: 19 August 2020

\begin{abstract}
Plasmonic metal nanoparticle (NP)-decorated thin films of biobased and biocompatible polymers provide significant opportunities in various biomedical applications. Inspired from the adhesive proteins of the marine mussels, polydopamine (PDA) serves as a versatile, biocompatible, and simple thin-film material and enhances cell growth and proliferation. Herein, we report the fabrication of the gold NPs (AuNPs) or silver NPs (AgNPs)-deposited thin films of PDA and their employment in cell growth and proliferation. PDA thin film with its numerous functional groups enabled well-controlled adsorption of NPs. The number density of NPs was manipulated simply by tuning the deposition time. Cell viability test for human lung cancer (A549) and human colon cancer (CaCO2) cell lines indicated that a thin layer of PDA film remarkably enhanced the cell growth and proliferation. The lower number density of NPs for the $24 \mathrm{~h}$ of the culture time resulted in a higher proliferation rate. However, the increase in both the number density of NPs and culture time led to a decrease in cell growth.
\end{abstract}

Keywords: polydopamine thin films; cell proliferation; gold nanoparticles; silver nanoparticles; cell viability

\section{Introduction}

The adhesive proteins of marine mussels facilitate the attachment of these organisms to the rocks and ships in seawater [1]. In the seminal work by Messersmith group, polydopamine (PDA) was proposed to mimic adhesive proteins of mussels, and various surfaces were deposited with these bioinspired polymers by simply oxidative polymerization of dopamine in alkaline conditions [2]. The PDA layer with its numerous functional groups provides many advantages in terms of versatility, biocompatibility, and simplicity [3]. With these unique characteristics, PDA was employed in various biological and medical applications, including drug carrier systems, tissue engineering, and vascular stents [3-8]. Due to its high level of biocompatibility and inconsiderable toxicity against biological structures such as cells, it can be used as a surface coating to enhance cell adhesion and proliferation [9]. Various studies demonstrated that PDA facilitated cell growth and proliferation on polyethylene and silicon rubber surfaces where the cell attachment was low [10,11]. In another study, Lee et al. investigated the adhesion of the bone marrow cells and fibroblasts onto the PDA-coated substrates [2]. While fibroblast cells showed significant performance in terms of cell adhesion and proliferation, these performances of bone marrow cells remained limited, indicating the cytophobic or cytophilic nature of PDA depending on the cell line. Additionally, the Park group reported the proliferation of human 
umbilical vein endothelial cells onto the PDA-coated electrospun polycaprolactone nanofibers [12]. The employment of the PDA layer remarkably increased the cell adhesion, number density of the cells, and cell viability, indicating the PDA-coated nanofibers as an ideal system for vascular tissue applications. Additionally, Ku et al. reported the PDA coated onto the pattern of poly(dimethylsiloxane) (PDMS) and the attachment and proliferation of different cell lines, including fibrosarcoma, mouse preosteoblast, and mouse fibroblast [13]. They observed that the cells were aligned in the direction of the patterned PDA substrate. Based on the previous studies, coating of the surfaces and nanoparticles with PDA helps to improve their biocompatibility and bioactivity, which will enhance their use in biological and biomedical applications [14-16].

Plasmonic metallic nanostructures such as gold nanoparticles (AuNPs) and silver nanoparticles (AgNPs) having unique properties due to their interaction with electromagnetic radiation provide various opportunities in biological and medical applications [17-19]. These plasmonic NP systems are utilized in a wide range of bio-applications, such as imaging, diagnostics, and therapeutics [20-22]. Despite their undoubted advantages, metallic NPs still have substantial toxicity problems that limit their employment, especially in cell adhesion and proliferation [23-25]. It is clear that novel and creative approaches are urgently required to extend and enhance their applications by increasing their biocompatibility and bioactivity.

The thin films of bio-based materials serve superior capabilities for biological and medical applications [26,27]. Mechanical properties, surface morphology, and the chemical composition of these films can be manipulated by combining macro- or nanoscale materials for cell growth and proliferation applications [28-31]. Despite the employment of the PDA thin films in various biomedical applications, the reports on plasmonic NPs and their cell interaction in terms of cell viability, adhesion, and proliferation are still limited. In this study, we propose the fabrication of the AuNPs or AgNPs decorated with PDA thin films and their usage in cell growth and proliferation of different cell lines including human lung cancer (A549) and human colon cancer (CaCO2). In our previous research, we observed that a thin layer of PDA onto the AgNPs dramatically reduced the cytotoxicity of NPs in two different cell lines [32]. PDA thin film with its numerous functional groups enabled well-controlled adsorption of NPs over time. It was detected that the PDA film remarkably contributed to the improvement in both cell growth and proliferation. The lower number density of NPs for the $24 \mathrm{~h}$ of the culture time resulted in a higher proliferation rate. However, the increase in both the number density of NPs and culture time led to a decrease in cell growth. In light of these findings, we strongly believe that the proposed system can be used in diverse biological and medical applications.

\section{Experimental Section}

\subsection{Synthesis of AgNPs and AuNPs}

We employed a citrate-reduction method to synthesize AgNPs with some modifications according to our earlier reports [32,33]. In brief, the proper amount of aqueous solution of $\mathrm{AgNO}_{3}(25 \mathrm{~mL}, 1 \mathrm{mM})$ was heated to boiling under vigorous stirring through a magnetic bar in a three-neck round-bottom flask. The silver ions were reduced by the addition of a drop-by-drop tri-sodium citrate solution $(1 \%, 1.65 \mathrm{~mL})$. After the termination of the conversion in $1 \mathrm{~h}$, the heater was turned off and the AgNPs suspension was cooled to ambient temperature. The AgNPs were purified by centrifugation at 15,000 rpm for $20 \mathrm{~min}$, and redispersed in deionized (DI) water.

Similarly, AuNPs were prepared according to the well-known citrate-reduction method with some modifications, which was shown in our earlier reports [34-39]. Briefly, the proper amount of aqueous solution of $\mathrm{HAuCl}_{4}(50 \mathrm{~mL}, 1 \mathrm{mM})$ in a three-neck round bottom flask was heated to boiling under vigorous magnetic stirring. Afterward, $1.65 \mathrm{~mL}$ of $0.1 \mathrm{M}$ trisodium citrate solution was added to the boiling mixture for the reduction of the gold ions. The resultant ruby-red colored AuNPs were observed in $30 \mathrm{~min}$, and the reaction was terminated by turning off the heater. The AuNP suspension was cooled to room temperature, centrifuged at 15,000 rpm for $20 \mathrm{~min}$, and re-dispersed in DI water. 


\subsection{Preparation of PDA,PDA@AgNP,PDA@AuNP 1 , and $P D A @ A u N P_{2}$ Thin Films}

Before the fabrication of the thin films, the glass slides with a $15 \mathrm{~mm}$ diameter that exactly fit 24-well plates were cleaned by sonicating consecutively in ethanol and acetone for $20 \mathrm{~min}$. Then, the slides were immersed into a mixture of $\mathrm{H}_{2} \mathrm{SO}_{4}$ and $\mathrm{H}_{2} \mathrm{O}_{2}$ with a volume ratio of 3:1 for $2 \mathrm{~h}$. Finally, the surfaces were washed with DI water and stored in ethanol until the next step. Before the thin film fabrication, the glass slides were dried with $\mathrm{N}_{2}$ gas flow. The PDA thin film was prepared by simply immersing the slides into a dopamine solution ( $\mathrm{pH} 8.5,2 \mathrm{mg} / \mathrm{mL}$ in $10 \mathrm{mM}$ Tris buffer) at ambient conditions for $2 \mathrm{~h}$. Afterward, the coated slides were rinsed with DI water and dried with $\mathrm{N}_{2}$ flow. For the decoration of metallic NPs, the PDA deposited surfaces were treated with NP suspensions of AgNPs and AuNPs (both in $50 \mathrm{ppm}$ ) for $3 \mathrm{~h}$. These NPs decorated slides were denoted as PDA@AgNP, PDA@AuNP 1 . For the comparison, a group of PDA-coated slides were immersed into the AuNP suspension for $24 \mathrm{~h}$ (denoted as PDA@AuNP 2 ). Finally, the NP-deposited thin films were rinsed with DI water and dried with $\mathrm{N}_{2}$ flow.

\subsection{Characterization of NPs and Thin Films}

The UV-Vis absorption spectra of NP suspensions and NP-deposited thin films were obtained through a Shimadzu 3600 Plus UV-Vis-near-IR spectrophotometer (Shimadzu, Kyoto, Japan). Transmission electron microscopy (TEM) and scanning electron microscopy (SEM) images were collected from Hitachi HighTech HT7700 (Hitachi, Tokyo, Japan) and Zeiss Sigma 300 (Zeiss, Oberkochen, Germany), respectively. The size distributions and surface coverage density of NPs onto the thin PDA films were calculated via freeware ImageJ software (1.8.0, The National Institutes of Health, Bethesda, MD, USA). The formation of the PDA thin film onto the glass slides was also analyzed through Fourier transform infrared spectroscopy (FT-IR, Bruker VERTEX 70v, Billerica, MA, USA).

\subsection{Cell Culture and Cell Adhesion to Thin Films}

Human lung cancer (A549) and colon cancer (CaCO2) cell lines were employed for cell culture studies to determine cell adhesion and following cell viability on the surfaces. A549 and CaCO2 cells were grown in RPMI 1640 and Dulbecco's Modified Eagle's Medium (DMEM), respectively. The media were supplemented with $10 \%$ Fetal Bovine Serum (FBS) and 1\% Penicillin/Streptomycin. The culture flasks were incubated in an incubator for $24 \mathrm{~h}$ maintaining $5 \% \mathrm{CO}_{2}$ and $90 \%$ humidity for proper cell growth. After cell proliferation on the culture, flasks reached $85 \%-90 \%$ confluency; the cells were detached from culture flasks with $0.25 \%$ trypsin ethylene-diamine-tetraacetic acid (EDTA). The as-prepared glass surfaces (PDA, PDA@AgNP, PDA@AuNP 1 , and PDA@AuNP ${ }_{2}$ ) were cleaned by soaking into $70 \%$ ethanol. Surfaces were immediately sterilized under UV light for $5 \mathrm{~h}$. Sterile surfaces were placed into 24 -well plates, and $7500 \mathrm{cells} / \mathrm{mm}^{2}$ in $150 \mu \mathrm{L}$ medium were seeded onto the surfaces. Then, the surfaces were kept at $37^{\circ} \mathrm{C}$ in a $5 \% \mathrm{CO}_{2}$ and $90 \%$ humidified incubator for 24 and $48 \mathrm{~h}$ via renewing the media every day. Coated specimens were washed with phosphate-buffered saline (PBS), and cells were fixed with a $4 \%$ paraformaldehyde solution for $1 \mathrm{~h}$. The specimens were stained with crystal violet dye and fluorescent DAPI stain for checking the cellular morphology, and unattached dye was washed with distilled water. After the coatings were dried, cell images were obtained with an inverted light microscope (Zeiss Primovert, Oberkochen, Germany) and a confocal laser scanning microscope (Zeiss LSM 710, Oberkochen, Germany) at different magnifications.

\subsection{Cell Viability (MTT Assay)}

Colorimetric MTT assay was performed to investigate the cellular viability on coated glass surfaces. The method is based on the fact that the living cells are capable of reducing the yellow-colored tetrazolium salts into intensely purple-colored formazan crystals. This reduction requires functional mitochondria, which is a cellular indicator for intact cells. 
Briefly, 7500 cells $/ \mathrm{mm}^{2}$ were seeded onto surfaces and grown at $37{ }^{\circ} \mathrm{C}$ in a $5 \% \mathrm{CO}_{2}$ and $90 \%$ humidified incubator for 24 and $48 \mathrm{~h}$. After the incubation period, the medium was removed and unattached cells were rinsed with PBS. The cells on the surfaces were treated with $100 \mu \mathrm{L}$ of MTT (3-(4,5-Dimethylthiazol-2-yl)-2,5-diphenyltetrazolium bromide salt) containing media and incubated for $4 \mathrm{~h}$ in $\mathrm{CO}_{2}$ incubator. At the end of the incubation period, the MTT solution was taken away from the surfaces and the formed purple-colored formazan crystals were dissolved with $200 \mu \mathrm{L}$ of dimethylsulfoxide (DMSO). The supernatants were transferred into 96-well plates, and the absorbance was measured at $570 \mathrm{~nm}$ using an ELISA reader (Epoch Microplate Reader, Vinooski, VT, USA) for determination of the cellular viability.

All the experiments were performed in triplicate and independently repeated at least three times. The results were shown as the mean \pm standard error of the mean (SEM) for triplicates of cultures. One way ANOVA test (GraphPad Prism 6.0, San Diego, CA, USA) was used to detect the effect of different surface modifications on growth and metabolic activity of $\mathrm{A} 549$ and $\mathrm{CaCO} 2$ cells (a value of $p<0.05$ was considered as significant).

\section{Results and Discussion}

\subsection{Characterization of NPs and Thin Films}

Firstly, for the characterization of NPs, we employed the UV-Vis absorption spectra and TEM analysis (Figure 1). Both AuNPs and AgNPs showed absorption maxima at 522 and $421 \mathrm{~nm}$, respectively (Figure 1a). TEM images depicted that the size of AuNPs was in the range of 15-40 nm, and the average size was found to be $26 \mathrm{~nm}$ (Figure 1b). The size of AgNPs was ranged from 30 to $80 \mathrm{~nm}$ with an average size of $53 \mathrm{~nm}$ (Figure 1c). Additionally, we employed the freeware ImageJ software for the analysis of the NPs, and relevant NP size histograms were given in Figure S1. From these data, we can conclude that both AuNPs and AgNPs were prepared efficiently with required morphology and appropriate size distributions.
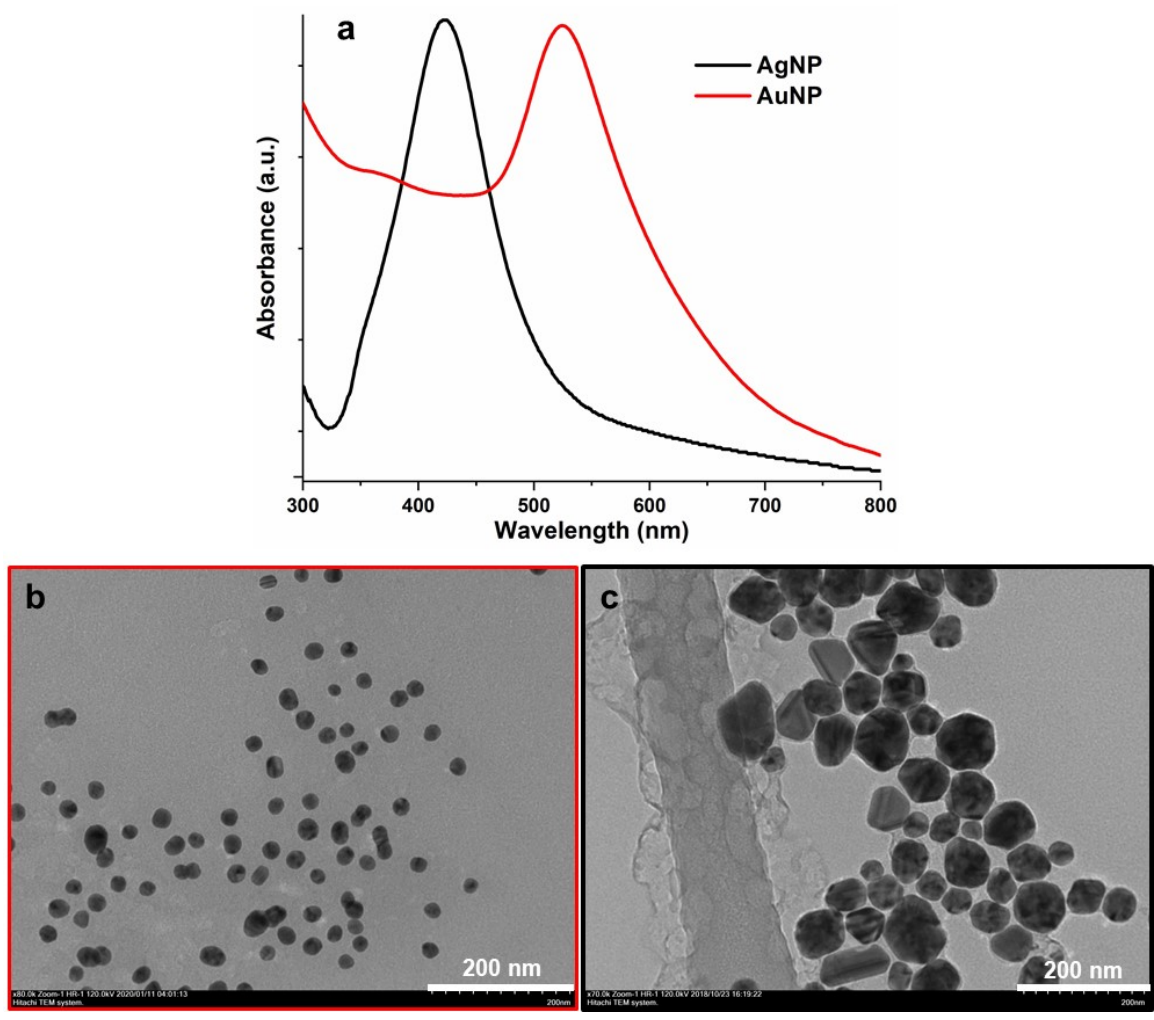

Figure 1. UV-Vis absorption spectra (a) and representative TEM images of gold NPs (AuNPs) (b), and AgNPs (c). 
After oxidative polymerization of dopamine, a thin layer of PDA was deposited onto the glass slides. The oxidative polymerization of the dopamine and deposition of the PDA onto the glass slides led to the emergence of the dark/brown color, which was observed by naked-eye. Our earlier studies depicted that a 2 h-polymerization time could create a PDA film with $8 \pm 1 \mathrm{~nm}$ thickness [32-36,40]. SEM images indicated the presence of a continuous, smooth, and thin layer of PDA film (data not shown). For further analysis, we obtained the FT-IR spectra of the PDA thin films summarized in Figure S2. We noticed broad bands in the range of $2800-3200 \mathrm{~cm}^{-1}$ for $v(\mathrm{~N}-\mathrm{H})$ and $v(\mathrm{O}-\mathrm{H})$ strong bands centered at 1282 and $1490 \mathrm{~cm}^{-1}$, which are ascribed to the $v(C=C)$ and $v(C-N)$ of the polydopamine coating, respectively [41,42]. The treatment of PDA-coated slides with metallic NPs led to the decoration of the NPs. Figure 2 summarizes the SEM images of PDA@AuNP, PDA@AuNP and PDA@AgNP thin films and their relevant UV-Vis absorption spectra. It is clear that PDA thin film with its numerous functional groups such as amine, imine, and catechol efficiently adsorbs NPs. The deposition of AuNPs for $24 \mathrm{~h}\left(\mathrm{PDA} @ \mathrm{AuNP}_{2}\right.$ ) resulted in higher surface coverage in comparison to 3 h-deposition time (PDA@AuNP 1 ). The 3h-deposition time formed rare and well-distributed AuNPs. However, for the case of PDA@AuNP 2 , the higher deposition led to the emergence of agglomeration of the AuNPs. The number density analysis of PDA@AuNP ${ }_{1}$ and PDA@AuNP 2 thin films through ImageJ software for each $1 \times 1 \mu \mathrm{m}^{2}$ area was calculated to be 172 and $1980 \mathrm{NPs} / \mu^{2}{ }^{2}$, respectively. Similar to the AuNPs, the AgNPs were well-distributed onto the PDA films. The number density of AgNPs was calculated to be $185 \mathrm{NPs} / \mu \mathrm{m}^{2}$. Furthermore, we performed the UV-Vis spectra to analyze the thin films (Figure 2). Due to the lower deposition of NPs, no distinctive absorption peak was detected for the PDA@AuNP 1 and PDA@AgNP thin films. However, for the case of PDA@AuNP2, a broad absorption spectrum with a maximum at $555 \mathrm{~nm}$ was noticed. Both red-shift and broadening in spectra are attributed to the change in dielectric constants and the agglomeration of the AuNPs. In our previous study, we detected that the existence, position, and intensity of the absorbance spectra of the plasmonic NPs decorated PDA thin film is highly dependent on the number of the deposited NPs [38]. We observed that as the number density of the deposited NPs were increased, both the intensity and degree of the red-shift with broadening in the absorption was increased, as well. In light of these data, we can conclude that the PDA layer can be decorated with AuNPs or AgNPs and the NP surface coverage can be manipulated simply by tuning the deposition time. 

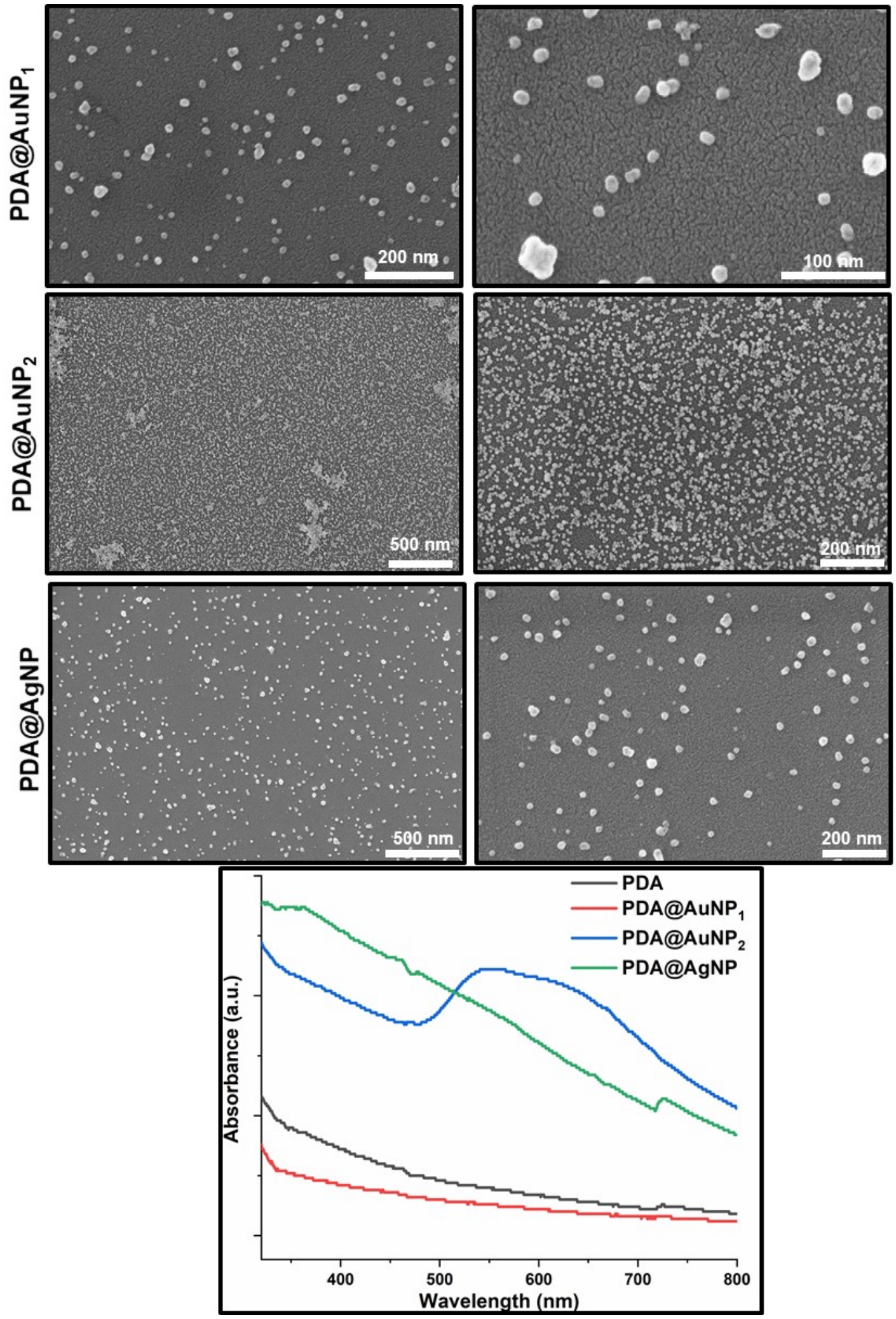

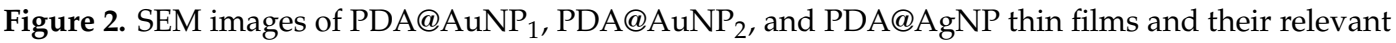
UV-Vis absorption spectra. 


\subsection{Biocompatibility Testing of Thin Films}

As the preliminary study, we tested the initial number of both cell lines onto the bare glass and PDA-coated glass. This analysis indicated that 7500 cells per well is satisfying for optimum cell growth and proliferation. The optic images of the preliminary analysis are summarized in Figure S3.

To determine the biological response of various surface coatings, human lung (A549) and colon cancer $(\mathrm{CaCO} 2)$ cells were selected and seeded onto the surfaces. After 24 and $48 \mathrm{~h}$ of cell growth, the cellular morphology was examined through crystal violet and DAPI staining, which was shown in Figure S4 and Figures 3 and 4. It was detected that the cellular morphology of the attached cells onto PDA and PDA@AuNP 1 surfaces was almost the same as the uncoated glass surfaces. The DAPI stain was penetrated healthy fixed cells. The cellular viability through the integrity of cell membranes was also demonstrated. The unchanged cell morphology and the interactions of cells with each other also contributed to understanding the cell behavior on the coated surfaces [43].

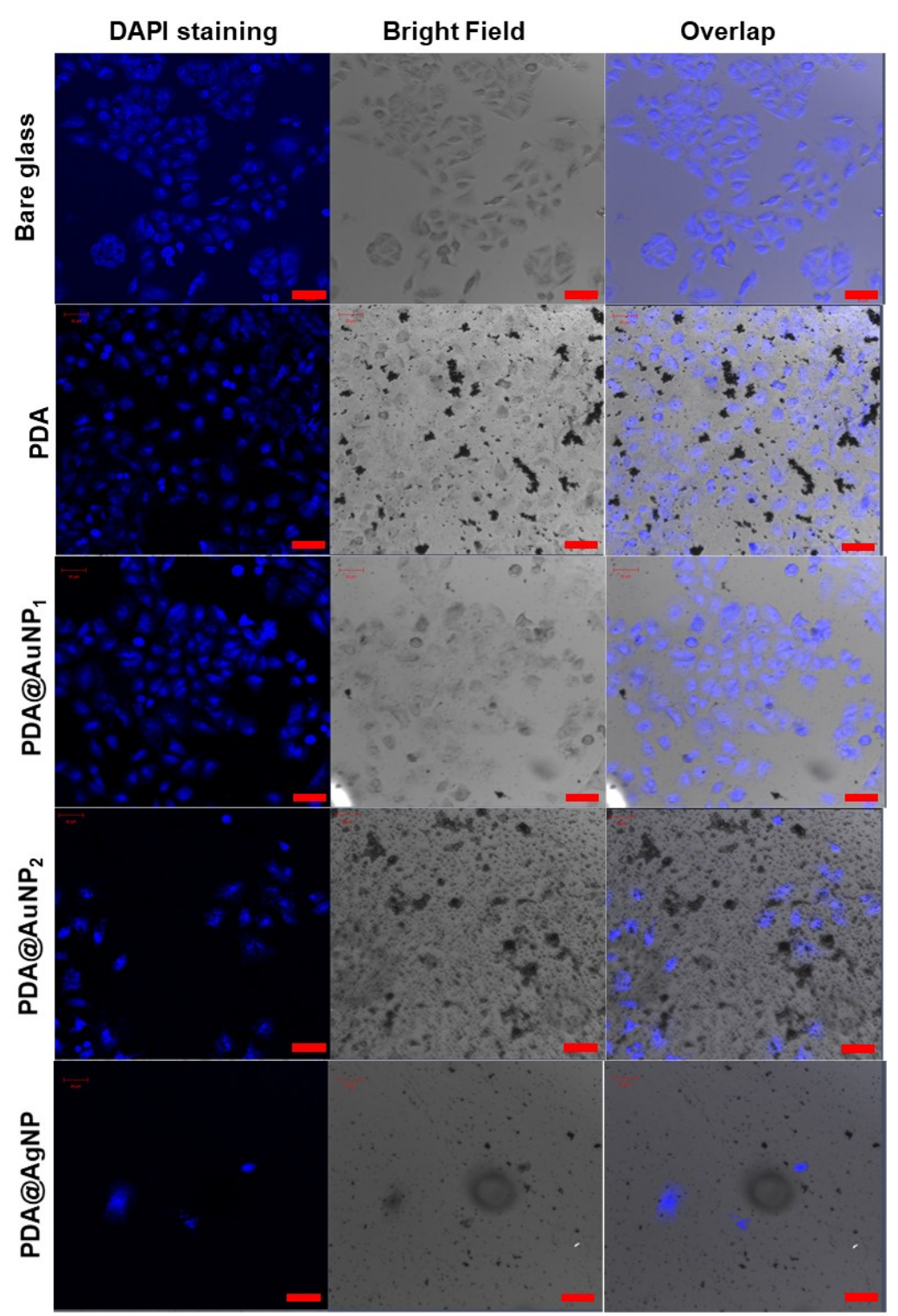

Figure 3. Confocal microscope images of A549 cells on different surfaces at $20 \times$ magnification. Scale bars are $50 \mu \mathrm{m}$. 


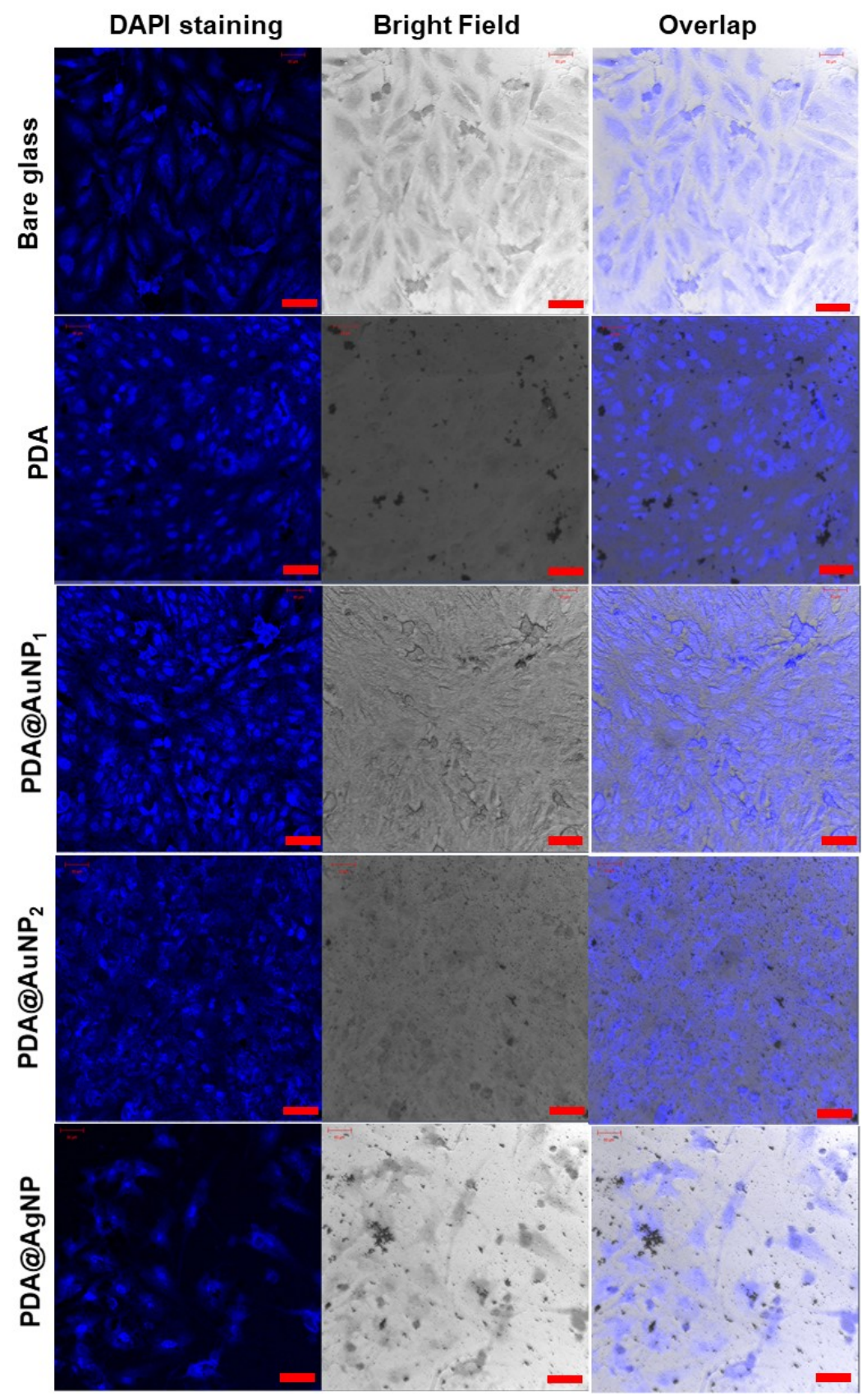

Figure 4. Confocal microscope images of $\mathrm{CaCO} 2$ cells on different surfaces at $20 \times$ magnification. Scale bars are $50 \mu \mathrm{m}$.

The cytotoxic effects of different surface coatings on A549 and $\mathrm{CaCO} 2$ cells were investigated by MTT assay after 24 and $48 \mathrm{~h}$ of culture. The MTT assay was performed to identify the cellular viability by measuring the optical density of solubilized formazan crystals at $570 \mathrm{~nm}$ (Figure 5). Cell proliferation on PDA-coated surfaces was significantly higher than glass surfaces for both cell types. For $24 \mathrm{~h}$ cell culture time, cell viability values were determined to be $146 \% \pm 3.3 \%$ and $118 \% \pm 2.9 \%$ for A549 and $\mathrm{CaCO} 2$ cell lines, respectively. Further, an increase in cell culture time $(48 \mathrm{~h})$ led to higher cell viability for the PDA-coated glass slides (149 \pm 1.1 for A549 and $151 \pm 2.1$ for CaCO2). This data depicts the high biocompatibility of bio-inspired PDA thin film [32]. PDA@AuNP1 surfaces did not decrease the number of viable cells when compared to the uncoated glass surfaces. For the case of PDA@AuNP1 surfaces at $24 \mathrm{~h}$ cell culture time, cell viability values were determined to be $97.3 \% \pm 1.5 \%$ and $104 \% \pm 5.1 \%$ for $\mathrm{A} 549$ and $\mathrm{CaCO} 2$ cell lines, respectively. However, the cellular viability began to 
decline at a high concentration of AuNPs for the case of the PDA@AuNP2 surface. Additionally, there was a significant decrease in viability on PDA@AgNP surfaces for the 24 and $48 \mathrm{~h}$ of the treatment. The employment of the PDA@AgNP surfaces resulted in lower cell viability values for $48 \mathrm{~h}$ cell culture time such as $25 \% \pm 3.5 \%$ and $27 \% \pm 1.9 \%$ for $\mathrm{A} 549$ and $\mathrm{CaCO} 2$ cell lines, respectively. For further analysis, we measured the number of adhered cells onto each thin film and summarized these results in Table S1. These data showed a high correlation between cell viability and adhered cell number density. Most of the cellular processes for adherent cells such as regulation of growth, proliferation, and cell survival partially or fully depend on the attachment of cells to a surface and contact with each other $[44,45]$. The affinity of cells to the substrate is crucial for the maintenance of cells on this substrate. Cell adhesion is followed by the spreading of cells on the substrate and an increase in cell number by proliferation. These results implicate that the attachment of the cells to the PDA deposited surfaces supported by the better viability of the cells on these thin films. Our findings demonstrated that a high concentration of Au and Ag was significantly reduced cell metabolism as compared to that of uncoated and PDA-coated surfaces. PDA-coated surfaces have been shown to possess lower cytotoxic effects and higher biocompatibility. It has been reported that surfaces and nanoparticles modified with PDA can promote cell adhesion and viability $[46,47]$. Accordingly, PDA and PDA@AuNP1 surfaces exhibited satisfactory cell adhesion and proliferation due to the potent adhesive characteristic of PDA. In contrast, the remarkable cytotoxicity of PDA@AuNP2 and PDA@AgNP coatings can be ascribed to the over-deposition of AuNPs and high cytotoxicity of AgNPs, respectively [32].
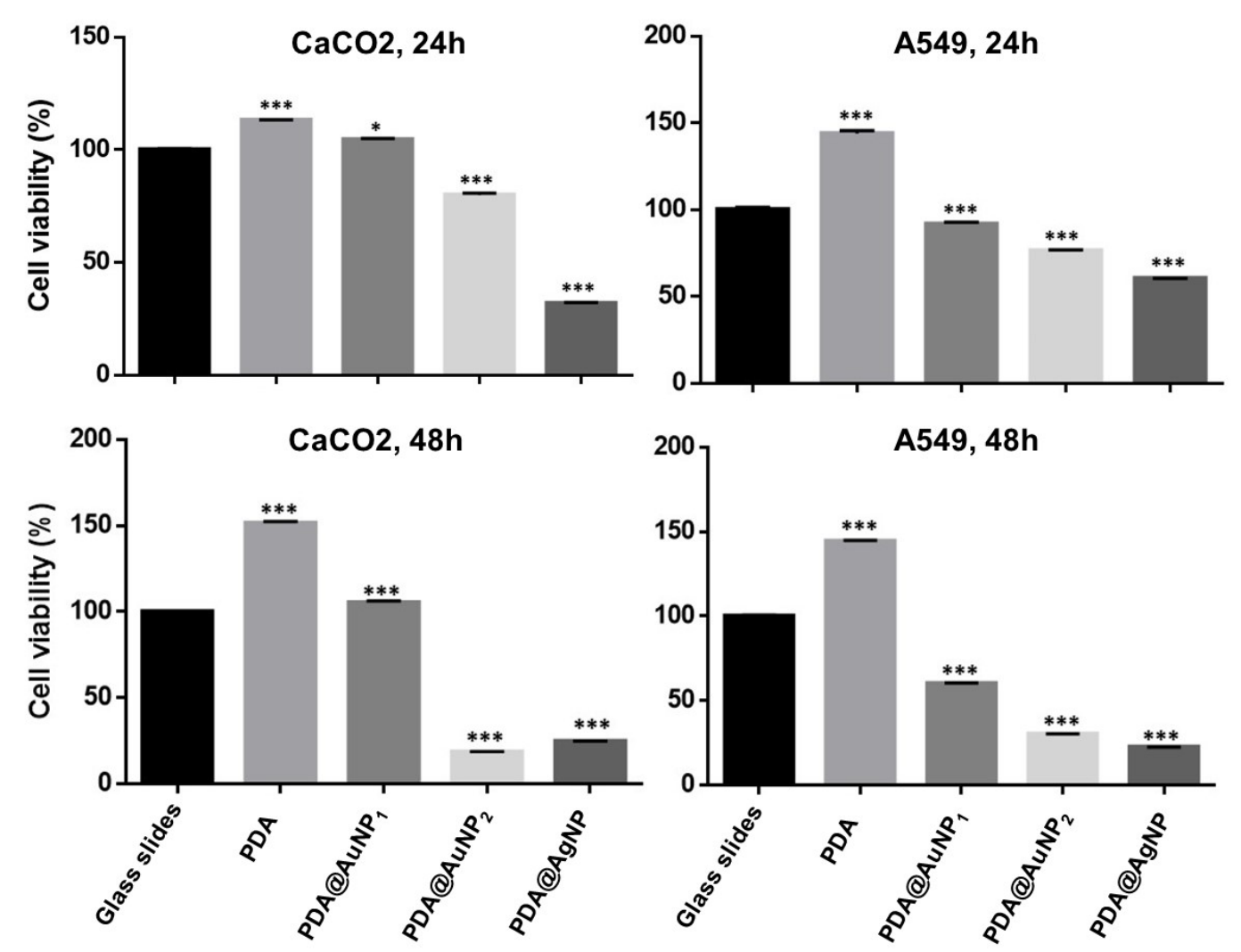

Figure 5. MTT assay of $\mathrm{CaCO} 2$ and A549 cells onto different surfaces after 24 and $48 \mathrm{~h}$ of cell culture. The number of asterisks indicates the significance of the alterations in the cell viability.

\section{Conclusions}

In summary, we sufficiently fabricated the AuNP or AgNP decorated the PDA thin films. The films were tested on two different cancer cell lines to determine cell viability, growth, and proliferation. We detected that the PDA layer remarkably enhanced cell growth and proliferation. The NP decorated films indicated that cell growth and proliferation is highly dependent on both the type and the number 
density of NPs. The highest cell viabilities were determined for the PDA-coated glass slides at $48 \mathrm{~h}$ cell culture time to be $149 \% \pm 1.1 \%$ and $151 \% \pm 2.1 \%$ for A549 and CaCO2 cell lines, respectively. However, the employment of the PDA@AgNP surfaces led to lower cell viability values for $48 \mathrm{~h}$ cell culture time such as $25 \% \pm 3.5 \%$ and $27 \% \pm 1.9 \%$ for $\mathrm{A} 549$ and $\mathrm{CaCO} 2$ cell lines, respectively. We envision that the proposed strategy can be extended to the various biomedical applications for the fabrication of biomedical devices and biomaterials with their flexible properties and functionality. AuNP or AgNP decorated the PDA thin films with their versatility, biocompatibility, and simplicity, and may provide opportunities in the fabrication of 3D tissue engineering scaffolds for bone or muscle regeneration, cell-based drug screening devices, and drug carriers in the vascular stents and analysis of cell-material interactions. Additionally, the surface plasmon resonance (SPR) nature of the AuNPs or AgNPs will pave the way for novel sensing systems such as surface-enhanced Raman spectroscopy (SERS) and surface-enhanced infrared spectroscopy (SEIR).

Supplementary Materials: The following are available online at http://www.mdpi.com/2079-6412/10/9/802/s1, Figure S1: Nanoparticle size distribution of AuNPs (a), and AgNPs (b); Figure S2: FT-IR spectrum of PDA thin film onto the glass slide; Figure S3: The preliminary study for the cell number optimization and optic images of A549 and $\mathrm{CaCO} 2$ cell lines incubated with an initial cell number of 7500 cells per well onto the bare and PDA coated glass; Figure S4: violet staining of $\mathrm{A} 549$ and $\mathrm{CaCO} 2$ cell lines onto different thin films at 20× magnification; Table S1: The number density of adhered cells onto the different substrates.

Author Contributions: Conceptualization, M.Y. and A.Y.; methodology, A.Y. and F.A.; validation, A.Y., M.Y., and F.A.; formal analysis, F.A.; investigation, A.Y., F.A., and M.Y.; resources, M.Y.; data curation, M.Y.; writing — original draft preparation, F.A. and M.Y.; writing - review and editing, A.Y., F.A, and M.Y.; visualization, M.Y.; supervision, M.Y.; project administration, M.Y.; funding acquisition, M.Y. All authors have read and agreed to the published version of the manuscript.

Funding: This research received funding from The Scientific and Technological Research Council of Turkey (TUBITAK, No: 119Z740).

Acknowledgments: This work was supported by The Scientific and Technological Research Council of Turkey (TUBITAK, No: 119Z740). The authors also kindly acknowledge the East Anatolia High Technology Application and Research Center (DAYTAM) at Ataturk University for providing laboratory spaces and the characterization devices.

Conflicts of Interest: The authors declare no conflict of interest.

\section{References}

1. Zhang, C.; Gong, L.; Xiang, L.; Du, Y.; Hu, W.; Zeng, H.; Xu, Z.-K. Deposition and adhesion of polydopamine on the surfaces of varying wettability. ACS Appl. Mater. Interfaces 2017, 9, 30943-30950. [CrossRef] [PubMed]

2. Lee, H.; Dellatore, S.M.; Miller, W.M.; Messersmith, P.B. Mussel-inspired surface chemistry for multifunctional coatings. Science 2007, 318, 426-430. [CrossRef] [PubMed]

3. E Lynge, M.; Schattling, P.; Städler, B. Recent developments in poly(dopamine)-based coatings for biomedical applications. Nanomedicine 2015, 10, 2725-2742. [CrossRef] [PubMed]

4. Postma, A.; Yan, Y.; Wang, Y.; Zelikin, A.N.; Tjipto, E.; Caruso, F. Self-polymerization of dopamine as a versatile and robust technique to prepare polymer capsules. Chem. Mater. 2009, 21, 3042-3044. [CrossRef]

5. Cui, J.; Yan, Y.; Such, G.K.; Liang, K.; Ochs, C.J.; Postma, A.; Caruso, F. Immobilization and intracellular delivery of an anticancer drug using mussel-inspired polydopamine capsules. Biomacromolecules 2012, 13, 2225-2228. [CrossRef]

6. Tsai, W.-B.; Chen, W.-T.; Chien, H.-W.; Kuo, W.-H.; Wang, M.-J. Poly(dopamine) coating of scaffolds for articular cartilage tissue engineering. Acta Biomater. 2011, 7, 4187-4194. [CrossRef]

7. Liu, Y.-T.; Kung, K.-C.; Yang, C.-Y.; Lee, T.-M.; Lui, T.-S. Engineering three-dimensional structures using bio-inspired dopamine and strontium on titanium for biomedical application. J. Mater. Chem. B 2014, 2, 7927-7935. [CrossRef]

8. Yang, K.; Lee, J.S.; Kim, J.; Bin Lee, Y.; Shin, H.; Um, S.H.; Kim, J.B.; Park, K.I.; Lee, H.; Cho, S.-W. Polydopamine-mediated surface modification of scaffold materials for human neural stem cell engineering. Biomaterials 2012, 33, 6952-6964. [CrossRef] 
9. Lee, Y.S.; Bae, J.Y.; Koo, H.Y.; Lee, Y.B.; Choi, W.S. A remote-controlled generation of gold@polydopamine (core@shell) nanoparticles via physical-chemical stimuli of polydopamine/gold composites. Sci. Rep. 2016, 6, 1-11. [CrossRef]

10. Ku, S.H.; Ryu, J.; Hong, S.K.; Lee, H.; Park, C.B. General functionalization route for cell adhesion on non-wetting surfaces. Biomaterials 2010, 31, 2535-2541. [CrossRef] [PubMed]

11. Liu, M.; Zeng, G.; Wang, K.; Wan, Q.; Tao, L.; Zhang, X.; Wei, Y. Recent developments in polydopamine: An emerging soft matter for surface modification and biomedical applications. Nanoscale 2016, 8, 16819-16840. [CrossRef] [PubMed]

12. Ku, S.H.; Park, C.B. Human endothelial cell growth on mussel-inspired nanofiber scaffold for vascular tissue engineering. Biomaterials 2010, 31, 9431-9437. [CrossRef] [PubMed]

13. Ku, S.H.; Lee, J.S.; Park, C.B. Spatial control of cell adhesion and patterning through mussel-inspired surface modification by polydopamine. Langmuir 2010, 26, 15104-15108. [CrossRef] [PubMed]

14. Hong, S.; Kim, K.Y.; Wook, H.J.; Park, S.Y.; Lee, K.D.; Lee, D.Y.; Lee, H. Attenuation of thein vivotoxicity of biomaterials by polydopamine surface modification. Nanomedicine 2011, 6, 793-801. [CrossRef] [PubMed]

15. Liu, X.; Cao, J.; Li, H.; Li, J.; Jin, Q.; Ren, K.; Ji, J. Mussel-inspired polydopamine: A biocompatible and ultrastable coating for nanoparticlesin vivo. ACS Nano 2013, 7, 9384-9395. [CrossRef] [PubMed]

16. Ma, L.; Qin, H.; Cheng, C.; Xia, Y.; He, C.; Nie, C.; Wang, L.; Zhao, C. Mussel-inspired self-coating at macro-interface with improved biocompatibility and bioactivity via dopamine grafted heparin-like polymers and heparin. J. Mater. Chem. B 2013, 2, 363-375. [CrossRef] [PubMed]

17. Khlebtsov, N.G.; Dykman, L.A. Optical properties and biomedical applications of plasmonic nanoparticles. J. Quant. Spectrosc. Radiat. Transf. 2010, 111, 1-35. [CrossRef]

18. Liao, H.; Nehl, C.L.; Hafner, J.H. Biomedical applications of plasmon resonant metal nanoparticles. Nanomedicine 2006, 1, 201-208. [CrossRef]

19. Sotiriou, G.A. Biomedical applications of multifunctional plasmonic nanoparticles. Wiley Interdiscip. Rev. Nanomed. Nanobiotechnol. 2012, 5, 19-30. [CrossRef]

20. Roy, S.; Gao, Z. Nanostructure-based electrical biosensors. Nano Today 2009, 4, 318-334. [CrossRef]

21. Boisselier, E.; Astruc, D. Gold nanoparticles in nanomedicine: Preparations, imaging, diagnostics, therapies and toxicity. Chem. Soc. Rev. 2009, 38, 1759. [CrossRef] [PubMed]

22. Smolková, B.; El Yamani, N.; Collins, A.R.; Gutleb, A.; Dusinska, M. Nanoparticles in food. Epigenetic changes induced by nanomaterials and possible impact on health. Food Chem. Toxicol. 2015, 77, 64-73. [CrossRef] [PubMed]

23. Duval, R.E.; Gouyau, J.; Lamouroux, E. Limitations of recent studies dealing with the antibacterial properties of silver nanoparticles: Fact and opinion. Nanomaterials 2019, 9, 1775. [CrossRef] [PubMed]

24. Abbasi, E.; Milani, M.; Aval, S.F.; Kouhi, M.; Akbarzadeh, A.; Nasrabadi, H.T.; Nikasa, P.; Joo, S.W.; Hanifehpour, Y.; Nejati-Koshki, K.; et al. Silver nanoparticles: Synthesis methods, bio-applications and properties. Crit. Rev. Microbiol. 2016, 42, 173-180. [CrossRef] [PubMed]

25. Ajnai, G.; Chiu, A.; Kan, T.; Cheng, C.-C.; Tsai, T.-H.; Chang, J. Trends of gold nanoparticle-based drug delivery system in cancer therapy. J. Exp. Clin. Med. 2014, 6, 172-178. [CrossRef]

26. Van Vlierberghe, S.; Dubruel, P.; Schacht, E. Biopolymer-based hydrogels as scaffolds for tissue engineering applications: A review. Biomacromolecules 2011, 12, 1387-1408. [CrossRef]

27. Lutolf, M.; Hubbell, J. Synthetic biomaterials as instructive extracellular microenvironments for morphogenesis in tissue engineering. Nat. Biotechnol. 2005, 23, 47-55. [CrossRef]

28. Stevens, M.M.; George, J.H. Exploring and engineering the cell surface interface. Science 2005, 310, 1135-1138. [CrossRef]

29. Bacakova, L.; Filová, E.; Parizek, M.; Ruml, T.; Švorčík, V. Modulation of cell adhesion, proliferation and differentiation on materials designed for body implants. Biotechnol. Adv. 2011, 29, 739-767. [CrossRef]

30. Dalby, M.J.; Gadegaard, N.; Oreffo, R.O.C. Harnessing nanotopography and integrin-matrix interactions to influence stem cell fate. Nat. Mater. 2014, 13, 558-569. [CrossRef]

31. Biggs, M.J.P.; Richards, R.G.; Dalby, M.J. Nanotopographical modification: A regulator of cellular function through focal adhesions. Nanomed. Nanotechnol. Biol. Med. 2010, 6, 619-633. [CrossRef] [PubMed]

32. Yilmaz, A. The employment of a conformal polydopamine thin layer reduces the cytotoxicity of silver nanoparticles. Turk. J. Zool. 2020, 44, 126-133. [CrossRef] 
33. Yilmaz, M. Silver-nanoparticle-decorated gold nanorod arrays via bioinspired polydopamine coating as surface-enhanced Raman spectroscopy (SERS) platforms. Coatings 2019, 9, 198. [CrossRef]

34. Yilmaz, A.; Yilmaz, M. Bimetallic core-shell nanoparticles of gold and silver via bioinspired polydopamine layer as surface-enhanced raman spectroscopy (SERS) platform. Nanomaterials 2020, 10, 688. [CrossRef] [PubMed]

35. Yilmaz, M. 3-D and plasmonic nanoparticle decorated catalytic system via bio-inspired polydopamine coating: Cigar filter case study. Hacet. J. Biol. Chem. 2019, 46, 515-521. [CrossRef]

36. Bakirci, G.; Yilmaz, M.; Babur, E.; Ozden, D.; Demirel, G. Understanding the effect of polydopamine coating on catalytic reduction reactions. Catal. Commun. 2017, 91, 48-52. [CrossRef]

37. Nasseri, B.; Yilmaz, M.; Turk, M.; Kocum, I.C.; Pişkin, E. Antenna-type radiofrequency generator in nanoparticle-mediated hyperthermia. RSC Adv. 2016, 6, 48427-48434. [CrossRef]

38. Yilmaz, M.; Bakirci, G.; Erdogan, H.; Tamer, U.; Demirel, G. The fabrication of plasmonic nanoparticle-containing multilayer films via a bio-inspired polydopamine coating. RSC Adv. 2016, 6, 12638-12641. [CrossRef]

39. Yilmaz, M.; Senlik, E.; Bişkin, E.; Yavuz, M.S.; Tamer, U.; Demirel, G. Combining 3-D plasmonic gold nanorod arrays with colloidal nanoparticles as a versatile concept for reliable, sensitive, and selective molecular detection by SERS. Phys. Chem. Chem. Phys. 2014, 16, 5563-5570. [CrossRef]

40. Akin, M.S.; Yilmaz, M.; Babur, E.; Ozdemir, B.; Erdogan, H.; Tamer, U.; Demirel, G. Large area uniform deposition of silver nanoparticles through bio-inspired polydopamine coating on silicon nanowire arrays for practical SERS applications. J. Mater. Chem. B 2014, 2, 4894-4900. [CrossRef]

41. Mazario, E.; Sanchez-Marcos, J.; Menendez, N.; Herrasti, P.; García-Hernández, M.; Muñoz-Bonilla, A. One-pot electrochemical synthesis of polydopamine coated magnetite nanoparticles. RSC Adv. 2014, 4, 48353-48361. [CrossRef]

42. Zangmeister, R.A.; Morris, T.A.; Tarlov, M.J. Characterization of polydopamine thin films deposited at short times by autoxidation of dopamine. Langmuir 2013, 29, 8619-8628. [CrossRef] [PubMed]

43. Sureshkumar, M.; Siswanto, D.Y.; Chen, Y.-C.; Lee, C.-K.; Wang, M.-J. Antibacterial and biocompatible surfaces based on dopamine autooxidized silver nanoparticles. J. Polym. Sci. Part B Polym. Phys. 2013, 51, 303-310. [CrossRef]

44. Yang, C.-Y.; Huang, L.-Y.; Shen, T.-L.; Yeh, J.A. Cell adhesion, morphology and biochemistry on nano-topographic oxidized silicon surfaces. Eur. Cell Mater. 2010, 20, 415-430. [CrossRef] [PubMed]

45. Khalili, A.A.; Ahmad, M.R. A review of cell adhesion studies for biomedical and biological applications. Int. J. Mol. Sci. 2015, 16, 18149-18184. [CrossRef] [PubMed]

46. Steffi, C.; Shi, Z.; Kong, C.H.; Wang, W. In vitro findings of titanium functionalized with estradiol via polydopamine adlayer. J. Funct. Biomater. 2017, 8, 45. [CrossRef]

47. Yin, Y.; Li, Y.; Cai, W.; Sui, J. One-step deposition of antibacterial Ag@PDA hybrid films on an NiTi alloy. RSC Adv. 2019, 9, 29263-29272. [CrossRef]

(C) 2020 by the authors. Licensee MDPI, Basel, Switzerland. This article is an open access article distributed under the terms and conditions of the Creative Commons Attribution (CC BY) license (http://creativecommons.org/licenses/by/4.0/). 